\title{
Urine TITIN N-fragment as a novel biomarker for critical illness myopathy: a pilot study
}

\author{
Hidehiko Nakano ${ }^{1 *}$, Tsunehiro Matsubara², Kazuma Yamakawa³ and Kensuke Nakamura ${ }^{1}$
}

\section{Main text}

Intensive care unit (ICU)-acquired weakness is a muscular weakness without other cause after intensive care and consisting of critical illness polyneuropathy and critical illness myopathy (CIM) [1]. Muscle atrophy can occur quite early during critical illness because of increased muscle protein breakdown (MPB) and decreased muscle protein synthesis (MPS) [1]. Although muscle mass can be evaluated using ultrasound [2] and computed tomography (CT) [3], MPS and MPB are difficult to evaluate separately. Muscle biopsy can directly evaluate MPB in CIM directly [4], but it is invasive. Creatine kinase cannot evaluate MPB in CIM [1]. Therefore, no noninvasive technique has been established.

Titin, the largest protein expressed specifically in striated muscle, becomes various fragments that are released into blood and urine after muscle damage. Reportedly, the N-terminal fragments of titin (N-titin) excreted in the urine are increased in patients with various muscular diseases [5]. Therefore, $\mathrm{N}$-titin is expected to be a noninvasive biomarker for monitoring MPB and we decided to evaluate the $\mathrm{N}$-titin levels in the acute phase of critically ill patients.

Subjects were four adult patients admitted to our ICU in September 2019. We calculated the correlation coefficient between mean values of $\mathrm{N}$-titin at days 1 ,
3, 5, and 7 and the femoral muscle mass (FMM) change between days 1 and 10 evaluated with CT. Urine $\mathrm{N}$-titin levels were measured using an enzymelinked immunosorbent assay kit (\#27900 Human Titin N-Fragment Assay Kit, Immuno-Biological Laboratories Co. Ltd., Fujioka, Japan). FMM was calculated using the same method we previously reported [3]. Statistical analysis was done using software: $R$, ver. 3.6.1.

Subjects were four adults for whom activities of daily living before admission were sufficient for their independent living. Basic characteristics and outcomes of the respective patients are presented in Table 1.

Figure 1 shows $\mathrm{N}$-titin changes of the respective patients. Mean N-titin levels of each patient were 42.93, 42.33, 21.62, and 29.69 ( $\mathrm{pmol} / \mathrm{mgCre}$ ). Their respective FMM changes were $-28.65,-19.03,-14.28$, and 20.96 (\%). The correlation coefficient between the mean value of $\mathrm{N}$-titin level and the FMM change was negative: $r=-0.729$. The mean values of creatine kinase for 10 days for the respective patients were $42.3,206.4,72.1$, and $31.7(\mathrm{U} / \mathrm{L})$.

The N-titin values of critically ill patients were remarkably high when entering the ICU. They persisted for at least 7 days. The values were negatively correlated with the rate of FMM change. An earlier study [5] revealed that $\mathrm{N}$-titin had a median of $1.2(\mathrm{pmol} /$

* Correspondence: be.rann1988jp@gmail.com

1 Department of Emergency and Critical Care Medicine, Hitachi General

Hospital, 2-1-1 Jonancho Hitachi, Ibaraki 317-0012, Japan

Full list of author information is available at the end of the article 
Table 1 Basic characteristics and results for each patient

\begin{tabular}{|c|c|c|c|c|c|c|c|c|c|c|c|c|c|c|c|c|c|}
\hline No. & Age & Sex & Diagnosis & SOFA & APACHEII & $\begin{array}{l}\text { Hospital } \\
\text { stay }\end{array}$ & $\begin{array}{l}\text { ICU } \\
\text { stay }\end{array}$ & $\begin{array}{l}\text { Days } \\
\text { on MV } \\
\text { until } \\
\text { day } 10\end{array}$ & $\begin{array}{l}\text { Total } \\
\text { steroids } \\
\text { dose } \\
\text { until } \\
\text { day } 10\end{array}$ & RRT & $\begin{array}{l}\text { Muscle } \\
\text { relaxant } \\
\text { use }\end{array}$ & Outcome & $\begin{array}{l}\text { Bl } \\
\text { at } \\
\text { day } \\
28\end{array}$ & $\begin{array}{l}\text { CK } \\
(\mathrm{U} / \mathrm{L}) \dagger\end{array}$ & $\begin{array}{l}\text { Cre } \\
(\mathrm{mg} / \\
\mathrm{dL}) \dagger\end{array}$ & $\begin{array}{l}\text { N-titin/ } \\
\text { Cre } \\
\text { (pmol/ } \\
\text { mgCre/ } \\
\text { dL)* }\end{array}$ & $\begin{array}{l}\text { FMM } \\
\text { change } \\
\text { (\%) }\end{array}$ \\
\hline 1 & 86 & $F$ & $\begin{array}{l}\text { Bacrerial } \\
\text { pneumonia }\end{array}$ & 6 & 15 & 20 & 9 & 5 & $\begin{array}{l}\text { PSL } 150 \\
\text { mg }\end{array}$ & - & - & Alive & 0 & 42.3 & 0.82 & 42.93 & -28.65 \\
\hline 2 & 48 & M & $\begin{array}{l}\text { Interstitial } \\
\text { pneumonia }\end{array}$ & 6 & 9 & 91 & 15 & 10 & $\begin{array}{l}\text { PSL } 360 \\
\text { mg } \\
\text { mPSL } \\
4000 \text { mg }\end{array}$ & - & - & Alive & 10 & 206.4 & 0.65 & 42.33 & -19.03 \\
\hline 3 & 86 & $F$ & $\begin{array}{l}\text { Congestive } \\
\text { heart } \\
\text { failure }\end{array}$ & 7 & 20 & 11 & 5 & 2 & $\begin{array}{l}\text { PSL } 180 \\
\mathrm{mg}\end{array}$ & - & - & Alive & 80 & 72.1 & 0.82 & 21.62 & -14.28 \\
\hline 4 & 60 & M & $\begin{array}{l}\text { Malignant } \\
\text { lymphoma }\end{array}$ & 8 & 11 & 33 & 14 & 9 & $\begin{array}{l}\text { PSL } 160 \\
\text { mg } \\
\text { HYD } \\
1200 \text { mg }\end{array}$ & - & - & Alive & 65 & 31.7 & 0.57 & 29.69 & -20.96 \\
\hline
\end{tabular}

SOFA Sequential Organ Failure Assessment, APACHE II Acute Physiological and Chronic Health Evaluation II, MV mechanical ventilation, RRT renal replacement therapy, BI Barthel Index, CK creatine kinase, N-titin urine titin N-fragment, Cre serum creatinine, FMM femoral muscle mass, PSL prednisolone, $m P S L$ methyl predonisolone, HYD hydrocortisone

${ }^{*}$ is for $\mathrm{N}$-titin/Cre(pmol/mgCre/dL); ${ }^{+}$is for $\mathrm{CK}$ and Cre

$\mathrm{mgCre} / \mathrm{dL})$ at rest in healthy individuals, 27.0 (pmol/ $\mathrm{mgCre} / \mathrm{dL}$ ) at the highest after $10 \mathrm{~km}$ running, and a median of 735.5 ( $\mathrm{pmol} / \mathrm{mgCre} / \mathrm{dL})$ in patients with Duchenne muscular dystrophy. Although the N-titin levels of these patients were much lower than those of the muscular dystrophy patients, FMM decreased during a short duration. Not prominent but continuous active MPB persisting for a week and reducing MPS from anabolic resistance and malnutrition might have produced these results.

Another previous study [6] showed that N-titin levels in healthy individuals decrease during the first 2 weeks of bed rest. However, the present study showed high values in critically ill patients at ICU admission. These findings suggest that $\mathrm{N}$-titin can reflect the pathological condition of MPB in CIM, which induced much more atrophy than muscle disuse.

No patient in this study was on dialysis. A molecular weight of $\mathrm{N}$-titin is about $26 \mathrm{kDa}$, and $\mathrm{N}$-titin is not removed by dialysis theoretically. Therefore, $\mathrm{N}$-titin measurements are expected to be effective for patients on dialysis.

In conclusion, $\mathrm{N}$-titin might be useful as a novel biomarker for MPB in CIM. For additional evaluation, a prospective observational study is underway at our hospital (UMIN000038353).

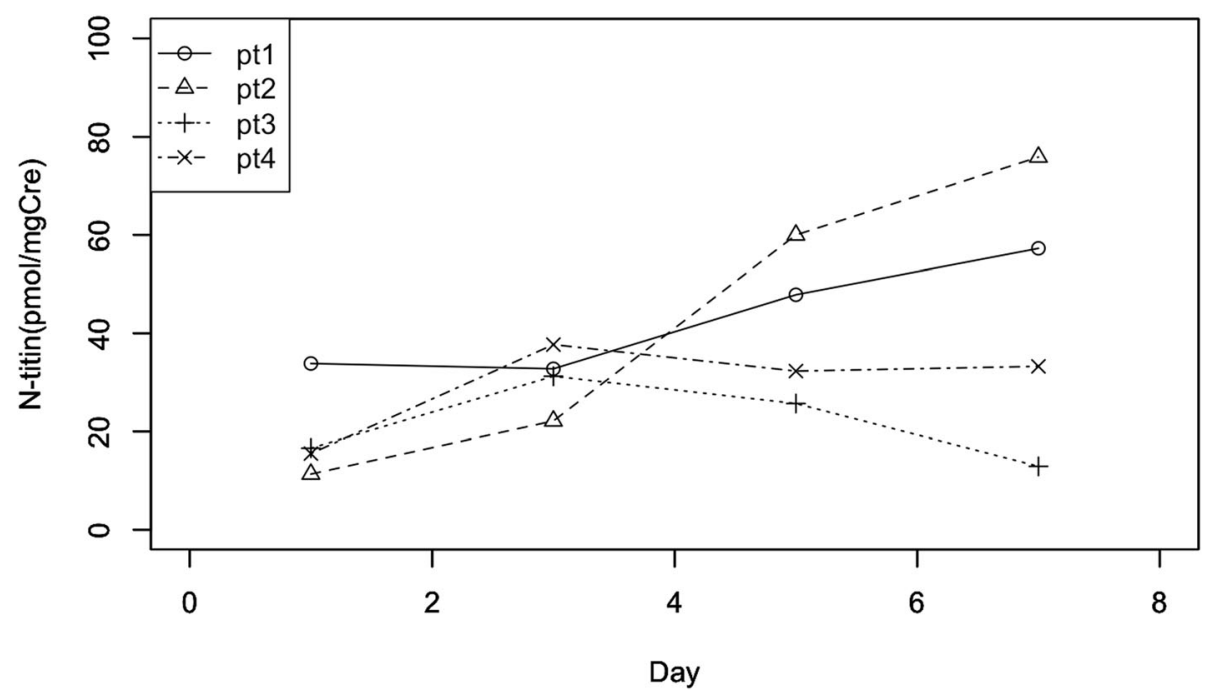

Fig. $1 \mathrm{~N}$-titin change of each patient. N-titin values were remarkably high when entering the ICU. They persisted for at least 7 days. $\mathrm{N}$-titin showed continuous increase in patients 1 and 2 and peaked on day 3 in patients 3 and 4 


\section{Abbreviations}

ICU: Intensive care unit; CIM: Critical illness myopathy; MPB: Muscle protein breakdown; MPS: Muscle protein synthesis; CT: Computed tomography; CK: Creatine kinase; N-titin: N-terminal fragments of titin; FMM: Femoral muscle mass

\section{Acknowledgements}

We would like to acknowledge all patients involved in this study. We would also like to thank ICU members and radiology technicians for supporting this study.

\section{Authors' contributions}

$\mathrm{HN}$ and $\mathrm{KN}$ developed the analysis plan. $\mathrm{N}$-titin measurement was performed by $\mathrm{TM}$ and $\mathrm{KY}$. HN undertook the main analysis with supervision from KN and $\mathrm{KY}$. HN wrote the first draft of the paper, with all other authors making important critical revisions. All authors have read and approved the final version of the manuscript.

\section{Funding}

No financial support was received for this study.

\section{Availability of data and materials}

The dataset is not available but can be requested from the corresponding author.

\section{Ethics approval and consent to participate}

$\mathrm{N}$-titin measurements for this study were taken using opt-out recruitment method, as approved by the Ethics Committee of Hitachi General Hospital (2019-37). These four patients were included in another study (UMIN000033783), and consent for CT imaging was already obtained for that study. We obtained written consent from all the patients to use their data for this report. All procedures performed in the study involving human participants were in accordance with the 1964 Declaration of Helsinki and its later amendments or similar ethical standards. Written informed consent from the enrolled patients was waived by the Ethics Committee because the urine samples were obtained after routine laboratory tests.

\section{Consent for publication}

Not applicable in this study.

\section{Competing interests}

The authors declare that they have no competing interests.

\section{Author details}

${ }^{1}$ Department of Emergency and Critical Care Medicine, Hitachi General Hospital, 2-1-1 Jonancho Hitachi, Ibaraki 317-0012, Japan. ²Department of Traumatology and Acute Critical Medicine, Osaka University Graduate School of Medicine, 2-2 Yamadaoka, Suita-shi, Osaka 565-0871, Japan. ${ }^{3}$ Division of Trauma and Surgical Critical Care, Osaka General Medical Center, 3-1-56 Bandai-higashi, Sumiyoshi-ku, Osaka-shi, Osaka 558-8558, Japan.

Received: 21 December 2019 Accepted: 21 March 2020

Published online: 28 April 2020

\section{References}

1. Hermans G, De Jonghe B, Bruyninckx F, Van den Berghe G. Clinical review: critical illness polyneuropathy and myopathy. Crit Care. 2008;12(6):238.

2. Seymour JM, Ward K, Sidhu PS, Puthucheary Z, Steier J, Jolley CJ, Polkey MI, Moxham J. Ultrasound measurement of rectus femoris cross-sectional area and the relationship with quadriceps strength in COPD. Thorax. 2009;64(5): 418-23.

3. Sonoo T, Hiromu N, Kibata A, Fukushima K, Daidoji H, Hashimoto H, Nakamura K. Muscle volume measurement for intensive care unit acquired weakness using computed tomography: a pilot study. J Med Diagn Methods. 2018;7:1.

4. Guarneri B, Bertolini G, Latronico N. Long-term outcome in patients with critical illness myopathy or neuropathy: the Italian multicentre CRIMYNE study. J Neurol Neurosurg Psychiatry. 2008;79(7):838-41.

5. Maruyama N, Asai T, Abe C, Inada A, Kawauchi T, Miyashita K, Maeda M, Matsuo M, Nabeshima Yl. Establishment of a highly sensitive sandwich ELISA for the N-terminal fragment of titin in urine. Sci Rep. 2016;6:39375.
6. Sun S, Henriksen K, Karsdal MA, Armbrecht G, Belavý DL, Felsenberg D, Rittweger J, Wang Y, Zheng Q, Nedergaard AF. Measurement of a MMP-2 degraded Titin fragment in serum reflects changes in muscle turnover induced by atrophy. Exp Gerontol. 2014;58:83-9.

\section{Publisher's Note}

Springer Nature remains neutral with regard to jurisdictional claims in published maps and institutional affiliations.

\section{Ready to submit your research? Choose BMC and benefit from:}

- fast, convenient online submission

- thorough peer review by experienced researchers in your field

- rapid publication on acceptance

- support for research data, including large and complex data types

- gold Open Access which fosters wider collaboration and increased citations

- maximum visibility for your research: over $100 \mathrm{M}$ website views per year

At $\mathrm{BMC}$, research is always in progress.

Learn more biomedcentral.com/submissions 